\title{
Human Resources Management and School Effectiveness in Government Technical Secondary and High Schools in Cameroon
}

\author{
Tam Vivian Ekwen, Prof. Fonkeng Epah George \\ Department of Educational Foundations and Administration, Faculty of Education, \\ University of Buea, Cameroon
}

\begin{abstract}
Management of resources is one of the areas in educational administration which brings about school effectiveness. When principals are provided with the human financial, material and time resources, they are most likely to perform their tasks effectively.
\end{abstract} Consequently, students' academic achievement is high and the organizational effectiveness is realized. This article is intended at exploring human Resources Management and School Effectiveness in government technical secondary and high schools in Fako Division, South West Region of Cameroon. The enquiry problem focused on the effectiveness of schools with respect to the management of human resources. Thus the link between human resources management and effectiveness of schools is at the center of this article. The implication is that; managing human resources can impact on school effectiveness. Data was collected from primary source through administration of open items questionnaires using a five point Likert scale format and closed ended questionnaires to two hundred and fifty respondents randomly sampled from ten technical secondary schools Fako Division. Secondary data was collected from documents such as journals and magazines from all necessary quarters and ChiSquare technique of data analysis was used to analyze the extent and impact of these variables on school effectiveness and whether there exists any relationship between Human Resources Management and School Effectiveness. The result obtained revealed that the null hypothesis was rejected at a calculated ChiSquare value greater than the critical value. This therefore led the researcher to conclude that Human Resources Management has a significant impact on School Effectiveness and that there exists a strong relationship between Human Resources Management and School Effectiveness; hence school administrators are advised to undergo courses in resources management, guide newly recruited teachers, and regular provide didactic materials to staff and stakeholders, with in-service training for staff.

Keywords: Management, human Resources Management, School Effectiveness, Government Technical Secondary and High Schools

\section{INTRODUCTION}

A resource is a useful or valuable possession or quality of a country, organization, or person. According to Nworgu (1991), the misappropriation of available resources and the poor management of other input components in education account for the ineffectiveness in schooling and educational systems as a whole especially in Africa. Negbo (2006) points out that trained principals excel in resource allocation and maintenance. They do so by ensuring the availability of the essential equipment and material, keeping an inventory of school property and outlying procedures for usage in the teachers' orientation and induction files. In Ojedele (2004), according to National Association for Elementary School Principals, known as N.A.E.S.P. (2003) school principals should develop plans for securing and allocating resources to meet high standards. Also Edem (1999) recommends that school administrators should adopt a policy of judicious usage of school property in order to ensure durability and maximum benefit. Furthermore, Ozigi (1998) supports that principals should come up with analysis of pedagogic material and other didactic kits together with Heads of Departments in order to ensure an effective teaching and learning process. When principals are provided with resources, they are most likely to perform their 
tasks effectively. Consequently, students' academic achievement is high and the organizational effectiveness is realized. Most public secondary and high school principals in Cameroon are provided with these resources. However, some principals try to neglect the utilization of the resources for selfish aims. Consequently, the misuse of these resources triggers organizational ineffectiveness. This has been a common phenomenon in our public secondary high schools and technical secondary schools in Cameroon. This reading therefore seeks to investigate and highlight how the management of human resources could bring about school effectiveness.

Within the national context, Timah (2013) opined that the poor management of educational resources especially the teaching personnel within the Cameroon secondary and technical education subsystem in terms of motivation is part of the causes of staff laxity and students poor performances in public examinations in many secondary institutions in the country. This is seen in the success rate of the result is on a down trend as for 2015 in CAP department of ESCOM and SEBU, there was a percentage passed of $78 \%$ for ESCOM and $76 \%$ for SEBU. In 2016, there was a drop in percentage passed of $48.54 \%$ for ESCOM and $45.31 \%$ for SEBU and for 2017 , the result further dropped to $26.67 \%$ for ESCOM and $28.26 \%$ for SEBU. This may imply that there has been an effect of management of resources on school effectiveness. In this connection, Ndongko (1989) says the increase in the number of untrained teachers in secondary schools makes it difficult for the schools to experience progressive teaching methods. She further argues that, this situation is worse when principals of schools themselves are untrained. The country's greatest resources is the dedication of it workers.

World Bank report on country issues (2006) for Cameroon states that; the educational system witnesses serious managerial and control malfunctioning. The solution adopted by the sector strategy consists in decentralizing management in order to reduce the uncertainty noted in the deployment of teachers. Accordingly, the Ministry of Basic Education will allocate a stock of teachers to the different regions and at this level, the teachers will be posted according to the needs notified in the field.

\section{Background of the Study}

According to Ihim (2003), Societies began with the development of skills within specialized domain like craftsmanship, blacksmithing, carpentry, building, trade by batter (business), with rudimentary tools to solve the immediate problems of the societies for economic growth. These aspects have developed to form the basis of Technical Education in most part of the world. In Cameroon, aspects of Technical Education were visible in (1841-1884) with the German take over in 1884, the primary schools curriculum included agriculture and manual craft with the ideas of some German philosophers such as; Pestalozzi (17641827), Froebel (1782-1814) and others. Specialized centers were also set up where graduates could learn carpentry, building and shoemaking in an organized manner.

This was the basis of the creation of the Ombe trade Centre in 1941 as a centre for training crafts men and technicians in Fako division as a mile stone in the advancements of Technical Education and Vocational training in the Southern Cameroon. As French Cameroon became independent in 1960, there / were only five full- fledged secondary grammar schools and one technical secondary school in all of Cameroon (Ihims, 2003). Since the late 70 s Cameroon has been undertaking comprehensive school reforms program in the management of Technical education with the creation of Higher Technical Teachers' Training Colleges in Douala in the year 1979, HTTTC Bambili in the year 2009, and Higher Technical Teachers' Training College, Kumba on the $7^{\text {th }}$ March 2014. This is because of the important role this type of education plays in the economy development, social life of a nation and consequently emergence. According to the sector wide approach of 2006, there has been an increase in the schooling rate in technical and vocational education at both cycles of about $7 \%$ of the total population of schooling age this has led to an increase in number of Technical Education schools created in the region as well. Technical education offers self-reliance development as stipulated by Law $\mathrm{N}^{\mathrm{o}} 98 / 004$ of $14^{\text {th }}$ April 1998 Section 4, the general goals of education shall be to train children for their intellectual, physical, civic and moral development and their smooth integration into society bearing in mind the prevailing economic socio-cultural and moral factor. This has been the aspirations of most youths in Cameroon to see it a reality rather than a 
mere promise.

However, in spite of these attempts by the Government to ameliorate Technical education, the training is still unable to meet up with the ever changing and demanding Cameroon society. Technical Education in South West Region still follows the Western Cameroon structure of education with most of the curriculum being imposed on the education system at different levels in different types of the institutions, both private and public. These levels include; Government Technical Colleges (GTC) which is the first cycle with a four years ending with CAP certificate and Government Technical High Schools (GTHS) with three years ending with two Certificates which include two years for probatoire and one year for Baccalaureate. In South West Region, Technical Education has always been considered second to the general education especially at the First cycle due to the fact that graduates are not regard as equivalents to their counterpart in general education and the certificates in most cases have no deserving category in the civil service payroll. To many today in South West Region, children admitted in Technical education are regarded as the dregs of primary schools. To be able to emerge and meet up with the competitive industrialized world, the management of resources in Technical schools has to be drastically improved and population attitude toward Technical Education need to be changed.

It should be noted here that management is not a new concept; it is as old as the history of the existence of human organizations. This concept has been expressed differently and takes different meaning depending on the context in which it is being used. The expression of the concept in the context of this study is in line with the idea of Mbua (2003) who states that management is the coordination of all educational resources through the process of planning, organizing, leading, and controlling in order to attain stated objectives. Every school irrespective of its size or where it is located needs enough resources in order to function. The major resources needed include finances, books, staff, buildings, areas of floor space and time. These resources are the means that are usually made available to the principal to be used for the achievement of the objectives of the school. In other words, the means could be financial, material or human.
Mbua(2003) states that, the educational administrator is an organizer and implanter of plans, policies and programmes meant for specific educational objective,. Furthermore, he defines the educational administrator as the person who is involved in the implementation of educational policies and programmes or the management of a school. Note should be taken here that the ministries of education in Cameroon are organized by decrees of the president of the republic; these ministries are responsible for the implementation of the country's education policies. For example, the presidential decree No 2005/139 of $25^{\text {th }}$ April, 2005 created and organized services in the ministry of secondary education(French acronym: MINESEC) in Cameroon for the purpose of improving the management of school resources (Tambo, 2003). Presidential decree No 2002/004 of $4^{\text {th }}$ January 2002, outlined four major functions of the school administrator. Which are; Pedagogic, administrative, financial and social functions. The social and administrative functions lay emphasis on the school administrator interpersonal relationships with staff, students and partners and with other series within the community. The financial function requires the school administrator to use the always limited resources available to the institution judiciously. The stability of any secondary schools depends largely on the effective management of the resources available to the institution by the school administrator.

\section{Statement of the Problem}

It is observed that schools are not effective in terms of achieving objectives of quality education. Quality is very important in all educational system but an elusive concept. The need to render school administration effective is very urgent especially now that the fight against poor academic performance, bribery, corruption, and embezzlement, has been intensified by the government. Through the ministry of secondary education, the government recruits new teachers and sends them to various public secondary schools all over the country every year. Some experience teachers are equally transferred from some schools to others according to need. In addition, financial resources which are called Running Credit are equally made available to schools two times in a year by the government. Government intention in providing all the above mentioned resources is to ensure school effectiveness. However, very often, 
public secondary and high school students' performance as compared to non-public schools both at the ordinary and advanced level general certificate of education examinations is poor. Given the assumption that some educational administrators have not received formal training in education administration, this leads them to experience difficulties in the management of school resources.

\section{Research Objective}

This study will investigate how; the management of human resources affects school effectiveness

\section{Research Question}

To what extent does the management of human resources affect school effectiveness?

\section{Hypothesis of the study}

The research question above was translated into both alternative and null hypotheses:

\section{Alternative Hypothesis}

Ha1: The management of human resources has a significant effect on school effectiveness.

\section{Null Hypothesis}

Ho1: The management of human resources has no significant effect on school effectiveness.

\section{Management of Human Resources and School Effectiveness}

Human resources refer to the personnel, staff or people who make up the work force of an organization. Management means the methods by which the leader utilizes material and human resources to achieve predetermined organizational goals (Owoeye, 2002). Thus, human resource management is the process that deals with utilizing people to perform duties and function in schools for effective goal attainment. Every educational system at every level depends heavily on teachers for the execution of its programmes. Maintaining and improving educational standards is only possible through teachers. The teacher, therefore, is the most indispensable entity in the school. He is the greatest aid to learning. Thus as far as possible, he should be thoroughly trained and supported in his work so that he/she can be successful in his duty task. Human resource management deals with the establishment of procedures for the employment and payment of workers or staff. It is the arrangement of. It is, therefore, an important function in the general context of all administrative responsibility of managing staff. It should also be remembered that the major premise of staff or human resources management in schools is that the end results of the educative process will be determined by the effectiveness of the school teachers. In dealing with staff or human resource management in schools, we are essentially concerned with three major issues namely: assessing the need for staff, satisfying the need for staff and maintaining and improving staff services. Finn (1999) observes that principals should treat their teachers as colleagues and not merely as subordinates. In agreement with this point, Negbo (2006) advices that principals should sue democratic administrative style through collegial model where teachers are directly involved in school administration.

Adding to the point Edem (1999) says the principal should incorporate the support staff as part of the school system by including them in administration through their staff representatives. He concludes that a school principal who is unable to develop the skills and knowledge of his / her teachers and use them properly will be unable to develop anything else. Whykstra (1971) confirms that investment in people makes it possible for an organization to tale advantages of technical progress and to continue with the progress. Section 37 of Law No. 98/004 of 14th April 1998 to lay dawn guidelines for education in Cameroon states that, the teacher is the principal guarantor of the quality of education. In this capacity, he or she shall be entitled, within the limited means available, to suitable living and working conditions, as well as to appropriate initial and continuing training (Tambo 2003).

Schools that suffer from greater levels of teacher shortage tend to have lower scores in Cameroon. Teachers are an essential resource for learning: the quality of a school system cannot exceed the quality of its teachers. Teachers interact with students daily and help students acquire the knowledge that they are expected to have by the time they leave school. Thus, attracting, developing and retaining effective teachers is a priority for public policy, although the policies related to teachers differ widely across countries (OECD, 2005). The type and quality of the training they receive, as well as the requirements to enter and progress through the teaching profession, have significant consequences on the quality of the teaching force. 


\section{Teacher training}

Competitive examinations are required to enter preservice teacher training (for public primary and secondary education). A competitive examination is required to enter the teaching profession for primary and secondary school in Cameroon and many other countries

\section{Teacher Profile and Qualifications}

More trained teachers $=$ better learning conditions for students in Cameroon Economic constraints in Cameroon contributed to a severe lack of teaching staff. A concerted education reform effort by the government supported by the global partnership and other development partners has led to putting more teachers where they are most needed to benefit a burgeoning school population that is eager to learn.

\section{The Challenge: Large Classes and Not Enough Teachers}

Class size can affect learning in various ways. Large classes may limit the time and attention teachers can devote to individual students, rather than to the whole class; and they may also be more prone to disturbances from noisy and disruptive students. As a result, teachers may have to adopt different pedagogical styles to compensate, which may, in turn, affect learning. The economic crisis of the 1980s prevented the government of Cameroon from hiring new teachers, while the number of students was growing at a steady pace. In some areas, the teacher shortage was so severe that communities resorted to hiring their own teachers. This led to the creation of three parallel tracks for teachers: those employed as civil servants, temporary teachers hired to fill gaps, and community teachers, often with minimal training, hired and paid by communities and parents. In the 1990s, teacher salaries were reduced because of budget cuts, and teacher recruitment stopped. The student to teacher ratio grew to more than 60 students per class, with significant variations among regions.

To remedy this, the government introduced the contract teacher program (CTP) in the late 1990s, but the program was lacking financial support.

The solution: supporting a country-driven solution Cameroon joined the global partnership in 2006 after the country's 2006-2015 education sector strategy was prepared with the local education group. To address the teacher shortage, the government started hiring more teachers and deploying them more equitably across the country to decrease large class sizes.

Cameroon committed nearly us $\$ 290$ million of its education budget to this program. The French development agency (agence française de développement) and the global partnership supported the government's goal, with us $\$ 55.3$ million and us $\$ 47.3$ million respectively. The global partnership for education (GPE) grant was used solely to pay teacher salaries. During the initial phase of the program, the government established clear policies to govern the hiring, salary scales, benefits, and career development of teachers. These reforms made the teaching profession attractive once again. The program was implemented by government institutions, making for a more efficient use of funds.

\section{The Results: Systemic Improvements in Teaching} and Learning

Between 2007 and 2011, 37,200 qualified primary school teachers were hired, 60 percent of them female. The increased presence of female teachers helped to get more girls in school, especially in the most underserved areas. The gender parity ratio increased from 63 girls for every 100 boys in 2006/07 to 89 girls for every 100 boys in 2010/11. Class sizes were also reduced across the country. GPE support for this initiative had a catalytic effect on the government's commitment to the teacher program, which is now a central component of the country's education sector plan. The Cameroonian government also demonstrated its commitment to education by increasing its domestic financing.

Since joining the global partnership in 2006 the country has increased public education expenditure as a share of the GDP by almost 14 percent. Thanks to GPE support, the government introduced better fiduciary policies and mechanisms, leading to faster and more efficient payment of teacher salaries. As a result, drop out and repetition rates declined between 2006 and 2010, and primary completion rates have increased. More finance will employ more teachers = more learning. During the next phase of its education strategy, Cameroon will focus on improving the quality of learning to ensure that all children go to school, learn, and become active and productive citizens. Public schools in Cameroon lack teachers while at the same time thousands of qualified teachers are unemployed. This is a regrettable squandering of human resources, all the more so considering that qualified teachers are hard to come by in many other 
African countries. Four teachers for six classes this is the reality at the state school in Balepipi (some 300 $\mathrm{km}$ northwest of Douala). Made up of three adobe bungalows, it suffers from a chronic shortage of teachers, as do many schools in Cameroon. Such a situation which some might consider normall for an African country is particularly regrettable in view of the fact that, at the same time, thousands of qualified teachers are unemployed or have gone on strike to demand the payment of over 30 months' salary arrears. At the end of December, the parents of the students at the Balepipi School did not renew the contract of the teacher whom they had been paying 10,000 cfa francs $(€ 15)$ per month ( 7 months a year) out of their own pocket to teach their children. Their hope was to obtain the appointment of a better qualified teacher whose salary would be paid by the ministry of basic education. As they say in Cameroon, that rare bird never came to roostll, in spite of the fact that the pupils' parents paid 70,000 cfa francs (the equivalent of the yearly salary of the dismissed teacher) to the ministry's local official in order to speed up the process. Having waited in vain for a new teacher, the headmaster, who was already in charge of the second-year intermediate class, now also has to teach the preparatory course. In Cameroon, there are officially some 11,000 primary state schools, with 55,266 primary school teachers catering for 3 million pupils. This gives us an average teacher/student ratio of 1:54, well below the minimum standard set by UNESCO, i.e. one teacher per 45 students.

\section{Theoretical framework}

\section{Goal Setting Theory of motivation; Locke Edwin 1968}

Goal Setting Theory was developed by Locke in 1968 in an article titled, toward a Theory of Task Motivation and Incentives. He stated that workers were motivated by clear goals and appropriate feedback. Locke went on to say that working towards a goal provided a major source of motivation to actually reach the goal which in turn improves performance. Locke's study showed that there was a relationship between how difficult and specific a goal was and people's performance of a task. Furthermore, he found that specific and difficult goals led to better task performance than vague or easy goals. For example, telling someone to Try hard or do your best is less effective than Try to get more than 80 percent correct. Hard goals are more motivating than easy goals, because it is much more of an accomplishment to achieve something that you have to work for.
Locke and Latham published a book titled A Theory of Goal setting and Task Performance. In the book, they projected five principles of goal setting. These principles are discussed below.

$>$ In the first place, Locke and Latham (1990) say that to be motivated, goals must have clarity. Clear Goals are measurable and unambiguous. One can ensure goal clarity by making them specific, measurable, and time-bound. Speaking on the importance of making goals specific, Awa (2007) says that the more specific the goal, the more concentrated the individual efforts will be in pursuit of the goal.

$>$ Secondly, to motivate, goals must be challenging and relevant. Challenging goals boast workers' enthusiasm and drive them to get the goals done.

Thirdly, to motivate, goals must be understood and agreed upon by workers. Agreed goals lead to commitment. This means that goals should be consistent and in line with previous expectations and organizational concerns. This requires that appropriate measures should be taken to involve workers in the goal setting programme of the organization.

Fourthly, to motivate, one must ensure that the work does not become overwhelming for tasks that are highly complex. Measures should be built in the goal setting expectations to account for complexity of the task. This requires that sufficient time be given to people to meet the goal or improve performance.

Fifthly, to motivate, an effective goal setting programme must include feedback or reports. Feedback provides opportunities to clarify expectations, adjust goal difficult, and gain recognition.

\section{Implications of goal setting theory}

To apply this goal setting theory to education administration, one can say that principals should understand the whole motive of goal setting is to facilitate success. It is powerful way of motivating school staff and oneself towards making school effective and efficient. Therefore school principals should apply the principles of goal setting in their administration. This can be done through the user of clear, challenging goals and commitment to achieving them. It can also be done through the provision of feedback on goal performance. They should equally take into consideration the complexity of the task. The observation of the principles of this theory will ensure much more success and the overall performance of the 
school will improve.

Apart from the goal setting theory, the human relation movement by Elton Mayo (1924), theory X and Theory Y by Douglas McGregor(1960) and Herzberg Two Factor Theory(1959) were also found relevant to the study. Goal setting theory is about setting goals for the achievement of organization objectives. Human relation movement theory on the other hand is concern with developing and maintaining dynamic and harmonic relationships. Theory $\mathrm{X}$ emphasizes the philosophy of direction, close supervision, external control and authoritarian and directive style of leadership. While theory $\mathrm{Y}$ projects a leadership style that is less directive and authoritarian.

\section{RESEARCH METHODOLOGY}

This study used the survey research design method. In this connection, opinions of people involved in the sample were gathered through the use of questionnaires which were constructed in relation to the variables under investigation. The collected responses were collected, analyzed and the results generalized to the entire population.

\section{Population of the Study}

The population consisted of all public technical secondary and high schools in Fako division. The list of all these schools was obtained from the Regional Delegation of secondary Education Buea. The population was made up of all the school administrators and teachers of government technical secondary and high schools in Fako Division amounting to 707 persons as distributed on the table above. Fako Division has a total of 10 government technical secondary and high schools in number which is the largest in the region in terms of number schools, students, teachers, administrators and infrastructures. The teacher population was 603, while there were 104 administrators and 6057 students. The population consisted of all public technical secondary schools in Fako and Meme divisions. Below is a table, illustrating the population distribution of government technical secondary and high schools in Fako Division.

Table1: Distribution of government technical/secondary and high schools in Fako Division, indicating students, teachers and school administrators in each school.

\begin{tabular}{|c|c|c|c|c|}
\hline School & $\begin{array}{l}\text { Student } \\
\text { Enrollment }\end{array}$ & $\begin{array}{c}\text { Administrative } \\
\text { Staff }\end{array}$ & $\begin{array}{l}\text { Teaching } \\
\text { Staff }\end{array}$ & $\begin{array}{c}\text { Infrastructure } \\
\text { (Permanent Structure) }\end{array}$ \\
\hline GTHS TIKO & 662 & 13 & 77 & 14 \\
\hline GTHS OMBE & 1076 & 14 & 109 & 45 \\
\hline GTHS MUYUKA & 737 & OIV. 14 & 80 & 12 \\
\hline GTHS MOLYKO & 1517 & 25 & 134 & 30 \\
\hline GTHS LIMBE & 923 & 9 & 67 & 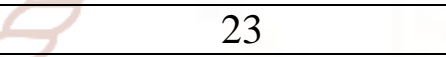 \\
\hline GTC MUNYENGE & 310 & $\begin{array}{r}6 \\
\end{array}$ & 5 & 8 \\
\hline GTC LYSOKA & 159 & 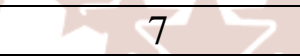 & $29 \square$ & 4 \\
\hline GTC EKONA & 378 & 8 & 39 & 4 \\
\hline GTC BOVA & 175 & $\sqrt{4.1}$ & 51 & 1 \\
\hline GTC BAKINGILI & 120 & 4 & 12 & 8 \\
\hline $\begin{array}{c}\text { TOTAL TECH } \\
\text { FAKO } \\
\end{array}$ & 6057 & 104 & 603 & 149 \\
\hline
\end{tabular}

Source: School Map Regional Delegation of Secondary Education South West Region, Cameroon.

\section{Sampling Technique and Sample}

The sample population was two hundred and fifty (250) respondents from ten (10) technical secondary schools from the Division. Fifty (50) administrators were selected from these ten schools and two hundred (200) teachers from the ten schools. The individual schools were selected using convenient sampling technique for their selection and geographical accessibility of the schools. All government technical schools in Fako division were used for this study. They are ten in number. The simple random sampling technique was used in selecting the teachers and administrators to answer the questionnaires, the researcher visited each school on different days and had a brief meeting with the principals of each school, presented her authorization letter from the Department of Educational Foundations and Administration, 
University of Buea to enable her carry out the data collection. The teachers present in school on that day were used to complete the questionnaires after a brief meeting and explanation to them on the purpose of the research and collection of data. The researcher also pleaded with them to be as objective as possible, as the data will be treated with utmost confidentiality.

Table 2: Effectives Sample of Teachers and Administrators

\begin{tabular}{|c|c|c|}
\hline \multirow{2}{*}{ School } & \multicolumn{2}{|c|}{ Fako Divisions } \\
\cline { 2 - 3 } & Number & $\%$ \\
\hline G.T.H.S Limbe & 30 & 12 \\
\hline G.T.C Bakingili & 10 & 4 \\
\hline G.T.H.S Ombe & 35 & 14 \\
\hline G.T.H.S Buea & 35 & 14 \\
\hline G.T.C Ekona & 25 & 10 \\
\hline G.T.C Lysoka & 20 & 8 \\
\hline G.T.H.S Muyuka & 35 & 14 \\
\hline G.T.C Munyenge & 05 & 2 \\
\hline G.T.H.S Tiko & 30 & 12 \\
\hline G.T.C Bova & 25 & 8 \\
\hline Total & 250 & 100 \\
\hline
\end{tabular}

Source: Regional Delegation of Secondary Education, South West Region, Cameroon. (2016)

\section{Instrument for Data Collection}

A questionnaire was designed for teachers and another one for administrators. The questionnaire was constructed in conformity with the research questions. 14 items of the questionnaire were for teachers while 14 others were for school administrators. The questionnaire comprised both close ended and open ended questions. There was a cover letter which carried the topic of the study and an appeal to respondents to complete it, stating clearly that confidentiality was to be respected, and that the responses were to be used strictly for the purpose of this research. A four point Likert type response options of strongly agree, agree, disagree, strongly disagree was used. The researcher personally served 200 teachers and 50 school administrators with the questionnaire. Some respondents completed and returned the questionnaire on the spot while others were collected at a later date.

\section{Method of Data Analysis}

Both descriptive and inferential statistics were used to describe the data gathered from the field and to verify the hypotheses. Computer software of SPSS package version 20 was used to bring out the tables for analysis, the statistical Chi-square result of expected and observed frequencies of the respondents. The collected responses were collected, analyzed and the results generalized to the entire population.

- Where the chi square $\left(\mathrm{x}^{2}\right)$ calculated value is greater than the chi-square critical value, we reject the null hypothesis and retain the alternative. Otherwise, the null hypothesis is retained, and the alternative rejected.

Where the null hypothesis is rejected and the alternative confirmed, the magnitude of the effect of the independent variable on the dependent variable is determined by comparing the contingency coefficient value (c.c.).

\section{FINDINGS: Data Analysis on Research Question:}

To what extent does the management of human resources affect school effectiveness?

Table 2: Human Resources management and School Effectiveness

\begin{tabular}{|c|c|c|c|c|c|c|}
\hline \multirow{2}{*}{ Count } & \multicolumn{5}{c|}{ School Effectiveness } & \multirow{2}{*}{ Total } \\
\cline { 2 - 7 } & Strongly Agree & 28 & 37 & 0 & 0 & 65 \\
\cline { 2 - 7 } & Agree & 0 & 59 & 80 & 0 & 139 \\
\cline { 2 - 7 } $\begin{array}{c}\text { Human Resources } \\
\text { management }\end{array}$ & Disagree & 0 & 0 & 18 & 12 & 30 \\
\cline { 2 - 7 } & $\begin{array}{c}\text { Strongly } \\
\text { Disagree }\end{array}$ & 0 & 0 & 0 & 10 & 10 \\
\hline & & 28 & 96 & 98 & 22 & 244 \\
\hline
\end{tabular}

Source: SPSS

From table 2 It is observed that sixty five respondents strongly agreed that human resources management affect school effectiveness, one hundred and thirty nine respondents agreed that human resources management affect school effectiveness, thirty respondents disagreed that human resources 
management affects school effectiveness and ten respondents strongly disagreed that human resources management affects school effectiveness.

Table 3: Chi-Square Tests

\begin{tabular}{|c|c|c|c|}
\hline & Value & Df & Asymp. Sig. \\
\hline Peasant Chi-Square & 283.964 & 9 & .000 \\
\hline Likelihood Ratio & 266.251 & 9 & .000 \\
\hline Linear-by-Linear & & & \\
\hline Association & 154.370 & 1 & .000 \\
\hline N of Valid Cases & 244 & & \\
\hline
\end{tabular}

The Chi-Square tests shows a calculated value of 283.964 as compared to the standard value of 16.919 at 9 degree of freedom and 5\% level of significance error. The likelihood ratio of 266.251 confirm the level of relationship between human resource management and school effectiveness and a linear-by-linear association of 154.370 confirmed the level of significance relationship between the two variables.

\begin{tabular}{|c|c|c|c|c|}
\hline & Value & $\begin{array}{l}\text { Asymp. } \\
\text { Std. Error }\end{array}$ & $\begin{array}{l}\text { Approx. } \\
\text { T }\end{array}$ & $\begin{array}{l}\text { Approx. } \\
\text { Sig. }\end{array}$ \\
\hline \begin{tabular}{c|c} 
& Phi \\
\end{tabular} & 1.079 & & & .000 \\
\hline Nominal by Cramer's V & .623 & & & .000 \\
\hline \begin{tabular}{|c|c} 
Nominal & $\begin{array}{c}\text { Contingency } \\
\text { Coefficient }\end{array}$ \\
\end{tabular} & .733 & & & .000 \\
\hline Interval by Pearson's R & .797 & .016 & 19.537 & .000 \\
\hline Ordinal by Spearman correlation & .782 & .021 & 20.531 & .000 \\
\hline $\mathrm{N}$ of Valid Cases & 244 & +7 & 8 & \\
\hline
\end{tabular}

From the Symmetric measures table, the Pearson's R Positive monotonic relationship between human of 0.797 shows that there exists a strong positive resources management and school effectiveness, linear relationship between Human resources hence school effectiveness depend on human management and school effectiveness and resource management. Spearman correlation of 0.782 confirm the strong

Table 5: Hypothesis Tests

\begin{tabular}{|c|c|c|c|c|c|}
\hline Hypothesis & $\begin{array}{c}\text { Standard } \\
\text { Chi-Square }\end{array}$ & $\begin{array}{c}\text { Calculated } \\
\text { Chi-Square }\end{array}$ & dfs & Decision & $\begin{array}{c}\text { Contingency } \\
\text { Coefficient }\end{array}$ \\
\hline $\mathrm{H}_{01}$ & 16.919 & 283.964 & 9 & $\begin{array}{r}\text { Reject } \mathrm{H}_{01}, \text { accept } \\
\mathrm{H}_{\mathrm{a} 1}\end{array}$ & 0.733 \\
\hline
\end{tabular}

From the table of hypothesis test, it is observed that the entire null hypothesis is rejected and the alternative hypothesis accepted hence, management of human resources has a significant effect on school effectiveness. The contingency coefficients have all the values above 0.5 which confirmed the rejection of the null hypothesis of the variable under study.

\section{Qualitative Data Analysis:}

Qualitative data was obtained from primary source from the open questions in the questionnaire based on the management of human resources and from secondary source from the detailed results analysis from the Regional Delegation of Secondary Education for the South West Region. The data is presented and analyzed as follows

Table 6: Qualitative data Analysis from Questionnaire

\section{Question}

In your opinion what should be done to improve on school effectiveness in human resources management?

\section{Grounding \\ Responses}

Teachers should put more effort in carrying out their duties, improve communication, school administration should be polite to staff, lack of competent personnel, provide means for seminars, teachers should be employed in department that are lacking, dialogue, train and employ qualified staff, motivate hardworking personnel with awards and letter of encouragement 
International Journal of Trend in Scientific Research and Development (IJTSRD) ISSN: 2456-6470

Table 7: Trend Analysis of Results from 2015-2017 in Fako Division

\begin{tabular}{|c|c|c|c|}
\hline \multirow{2}{*}{ Options } & \multicolumn{3}{|c|}{ Percentage pass per year } \\
\cline { 2 - 4 } & 2015 & 2016 & 2017 \\
\hline ESCOM & $78 \%$ & $48.54 \%$ & $26.67 \%$ \\
\hline SEBU & $76 \%$ & $45.31 \%$ & $28.26 \%$ \\
\hline
\end{tabular}

Source: Regional Delegation of Secondary Education for South-West Region, Cameroon

From the table it is observed that the success rate of the result is on a down trend as for 2015 , there was a percentage passed of $78 \%$ for ESCOM and $76 \%$ for SEBU. In 2016, there was a drop in percentage passed of $48.54 \%$ for ESCOM and $45.31 \%$ for SEBU and for 2017, the result further dropped to $26.67 \%$ for ESCOM and $28.26 \%$ for SEBU. This may imply that there has been an effect of management of human resource on school effectiveness as indicated on the poor performance of schools for the past three years. This information is presented on graph below

\section{Discussion of Findings}

The null hypothesis was rejected and the alternative hypothesis accepted that "management of human resources has a significant effect on school effectiveness." These findings are in line with the Besong, (2014) in his investigation of administrative effectiveness and their managerial implications towards staff productivity in terms of managing human and material resources, interpersonal relationship, managing school finance, discipline and motivation of staff. The researcher recommended that Induction courses should be organized for those promoted to the rank of principals, to acquaint with simple ethics of management and administration of human beings in schools.

The findings also tally with the study of Gumede (1999), in determining the effectiveness of the administrative and leadership roles of secondary school principals in the Durban South Region, and also investigated the challenges that are encountered by principals as secondary school administrators and leaders. The researcher recommendations made are a contribution towards transforming schools and leading them in a process which can truly enhance teacher effectiveness and create a culture which can foster the education of learners.

Babatunde, (2014) supported this hypothesis in his study where he examines the relationship between principals' managerial skills and administrative effectiveness in secondary schools in Oyo State, Nigeria. The findings revealed that there was significant relationship between principals' managerial skills and administrative effectiveness which tally very well with this hypothesis.

Also (OECD, 2005), supports that teachers are essential resources for learning: "the quality of a school system cannot exceed the quality of its teachers. Teachers interact with students daily and help students acquire the knowledge that they are expected to have by the time they leave school. Thus, attracting, developing and retaining effective teachers is a priority for public policy, although the policies related to teachers differ widely across countries The type and quality of the training they receive, as well as the requirements to enter and progress through the teaching profession, have significant consequences on the quality of the teaching force. More trained teachers $=$ better learning conditions for students in Cameroon Economic constraints in Cameroon contributed to a severe lack of teaching staff. A concerted education reform effort by the government supported by the global partnership and other development partners has led to putting more teachers where they are most needed to benefit a burgeoning school population that is eager to learn. Thus, human resource management is the process that deals with utilizing people to perform duties and function in schools for effective goal attainment. Every educational system at every level depends heavily on teachers for the execution of its programmes. Maintaining and improying educational standards is only possible through teachers. The teacher, therefore, is the most indispensable entity in the school. He is the greatest aid to learning. Thus as far as possible, he should be thoroughly trained and supported in his work so that he/she can be successful in his duty task".

Tambo, (2003) section 37 of Law No. 98/004 of $14^{\text {th }}$ April 1998 to lay dawn guidelines for education in Cameroon states that, the teacher is the principal guarantor of the quality of education. In this capacity, he or she shall be entitled, within the limited means available, to suitable living and working conditions, as well as to appropriate initial and continuing training. Teachers need to manage the resources put at their disposal for effective results in schools.

This is also in line with theory $\mathrm{X}$ and $\mathrm{Y}$ by McGregor where he said in theory $X$ that the average human 
being has an inherent dislike for work and will avoid it if possible due to this dislike for work most employees must be controlled, directed and threatened with punishment in order to get them work to accomplish organizational goals. The average human being prefers to be directed, wishes to avoid responsibility, has little ambition and wants security. If human are not well managed, we would not have an effective results. And in theory $\mathrm{Y}$ that under the conditions of modern industrial life, the intellectual potentialities of the average human being are partially utilized. This shows human resources have a great influence on resources management. Also the two factors theory by Herzberg states that; Motivation factors are needed to motivate an employee (human resource) to higher performance.

\section{Recommendations on human resources management and school effectiveness}

There is also need for yearly capacity building workshops and seminars for teachers and administrators of schools. This will go a long way in helping especially newly appointed administrators. Authorities have often focused their capacity building activities on teachers with very few focused on the administrator. Added to this, administrators have no special administrative training on how to effectively manage schools except for the little knowledge they received from the Teacher Training College.

$>$ Policies makers should recognize the importance of human resources management in our schools and see the need to create a department in teacher training colleges only to train administrators like the department of Educational Foundations and Administration in the University of Buea. That way we shall have full flesh trained administrators in our various secondary and high schools.

Authorities should ensure that teachers just coming from the Teacher Training Colleges are not appointed administrators. This is because effective administration requires some level of understanding and experience of the functioning of the school system. Teachers should spend at least five (5) years in school as classroom teachers before being appointed post of responsibilities

In addition to that, Teachers need to put more effort in carrying out their duties.

$>$ Improve communication

$>$ School administrators should be polite to staff

$>$ Teachers should be employed in department that are lacking
Dialogue should be the key in case of any misunderstanding

$>$ Administrators should motivate hardworking personnel with awards and letter of encouragement which is hardly done in these schools. This will greatly improve the quality of personnel we have in our school and the consequence result will be school effectiveness.

\section{Conclusion}

From these results, the researcher concluded that Human Resources Management Significantly affects school effectiveness. With all the calculated ChiSquare results greater than the standard values, it showed that the null hypothesis is rejected and the alternative hypothesis $\left(\mathrm{H}_{1}\right)$ is accepted that "Human Resources Management has a significance effects on school effectiveness", at 9 degree of freedom and 5\% level of significant error. The contingency coefficient of 0.733 shows the extent of the relationship between the independent variables which is Human Resources Management and the dependent variable which is School Effectiveness, with the value approaching one; it confirms the strong association of the variables under study.

(OECD, 2013), supports that; in Cameroon, there are officially some 11,000 primary state schools, with 55,266 primary school teachers catering for 3 million pupils. This gives us an average teacher/student ratio of 1:54, well below the minimum standard set by UNESCO, i.e. one teacher per 45 students.

Frankie-Dolor (2002:126-133) asserted that of all the pre-requisites for effective management of an organization, the most vital is the human resources. The success of any type of organization may be it social, political, religious or economic, depends to a large extent, on the human beings that make up the organization. Human beings take decisions, which provide the knowledge, energy and the co-operation through which organizational objectives are achieved.

Apart from human resources management there are other variables which also correlate to school effectiveness and we can't have effective schools if they are not focused on; Watson (1986) found out a number of characteristics for effective schools such as strong leadership, high expectations, and good atmosphere. The definition of effective schools differs from one researcher to the next. Some researchers have focused on academic achievement of the 
students. Other did research concerning differences in attitudes and behavior of the students (Dodson 2005).

Edmonds (1982) synthesized the research and identified some variables strongly correlated with school effectiveness such as strong administrative leadership, basic skill acquisition, high expectations for student achievement, a safe and orderly environment and frequent assessing of student achievement (Harbaugh 2005). In the literature this summarizing is sometimes identified as the five factor model of school effectiveness. Lezotte (1991) in conducting school effectiveness research found out seven correlates of effective schools which evolved the original correlates shared by Edmonds (1982) and added two variables by actual research findings: (1) instructional leadership, (2) clear vision and mission, (3) safe and orderly environment, (4) high expectations for students achievement, (5) continuous assessment of student achievement, (6) opportunity and time on task and (7) positive home-school relations. Student achievements should be the basic products of effective schools. Otherwise nobody can evaluate the effectiveness of school.

\section{References}

1. Awa, J. T (2007), the Relationship Between Entry Qualification And Academic Performance In The University Of Buea (M. Ed Thesis).

2. Babatunde (2014) Relationship between Principals' Managerial Skills And Administrative Effectiveness In Secondary Schools In Oyo State, Nigeria (Phd Thesis).

3. Besong, J. B. (2014). Principals' Administrative Effectiveness and Staff Productivity in Selected Secondary School in South West Region, Cameroon. International Journal of Academic Research in Management (IJARM) Vol. 3, No. 2, 2014, Page: 155-166, ISSN: 2296-1747 C Helvetic Editions LTD, Switzerland www.elvedit.com

4. Dodson, C. K. (2005). The Relationship between School Effectiveness And Teachers' Job Satisfaction In North Mississippi Schools (Unpublished Doctoral Dissertation). Mississippi University, Oxford.

5. Edem, D. A. (1999). Introduction to Education Administration in Nigeria. Ibandan: Spectrum Book Ltd
6. Edmonds, R. \& Frederikson, J. R. (1979). Search for effective schools: The identification and analysis of city schools that are instructionally effective for poor children. Cambridge, MA: Harvard University Center for Urban Studies. Evertson,

7. Finn, J, (1999). CM Tennessee's class size study: Findings, implications, and misconceptions Educational Evaluation and Policy Analysis 19992197109

8. Frankie-Dolor, T. R (2002). Evaluating resources for business education programme. In E. A Aromolaran (Ed). Book of reading in business education. I (1):126-133, Nigeria.

9. Gumede, B. J. (1999) Effectiveness of Administration and Leadership Roles in Secondary Schools In Principal. Enugu: computer Edge Publisher.

10. Harbaugh R. J. (2005). Examining the correlates of effective schools present in an intermediate school: A case study, Unpublished Doctoral Dissertation, Immaculate University, Pennsylvania

11. Herzberg, F. (1959). The Motivation to work (2nd ed.). New York: John Wiley and Sons.

12. Ihim, J. A. (2003), A Century of Western Education In Cameroon: A study of History and Administration, 1884-1961 Bamenda, Cameroon unique printers.

13. Lezotte, L. \& Passalacqua, J. (1978). Individual school buildings: Accounting for differences in measured pupil performance. Urban Education, 13, 283-293.

14. Locke, E. A. (1965). The relationship of task success to task liking and satisfaction. Journal of Applied Psychology, vol 2, 14-24.

15. Mbua, F. N. (2002) Educational Administration: Theory and Practice. Limbe: Desing House.

16. Mbua, F. N. (2003). Educational Planning: Issues and Perpectives. Limbe: Pressprint.

17. McGregor, D. (1960), Leadership and Motivation Essay. London: Mit press

18. Ndongko, T. M. (1989). A Handbook of Secondary Schools Administration. University Of Yaoundé (Thesis).

19. Negbo, E. P. (2006). Formal Training in Educational Administration: Assessing the need 
International Journal of Trend in Scientific Research and Development (IJTSRD) ISSN: 2456-6470

for Formal Training of Principals of Government Secondary Schools in Anglophone Cameroon (M. Ed Thesis).

20. Nworgu, T. (1991). Educational Research: Basic Issues and Methodology. Ibadan: Wisona Publisher

21. Ogundele, O. M., Sambo, A. M., \& Bwoi, M. G (2015). Principals' administrative skills for secondary schools in Plateau State, Nigeria. Asia Pacific Journal of Education, Arts and Sciences, 2(1), $90-96$.

22. Ojedele, P. K. (2004). Facilities Provision and Management of Schools for Successful Implementation of Universal Basic Education (UBE) Programme in Nigeria. Ibadan: NAEAP/CODAT Publication

23. Organisation for Economic Co-operation and Development. (2010). The high cost of low educational performance. An estimation of the long-run economic impact of improvements in PISA outcomes. Paris: Publisher.

24. Owoeye, J. S. (2000). The Effects Of Interaction Of Location, Facilities And Class size On Academic Achievement of Secondary School students In Ekiti State, Nigeria. An Unpublished Phd Thesis. University, Ibadan, Nigeria.

25. Ozigi, A. O. (1977). A Handbook On School And Management Administration. Lagos: Macmillann Nigeria publishers limited

26. Tambo, L. I. (2003). Cameroon National Education Policy since the 1995 Forum. Limbe: Design House

27. Timah, H. A. (1978). The new science of management decision. London, Englewood Cliffs: rentice-Hall.

28. UNESCO (2009). The quality of primary schools in different development contexts. Paris: UNESCO

29. Watson, T. (2000) Management, Organisation and Employment Strategy. London: Routledge \& Kegan Paul.

30. World Bank (2004a). Uganda Tertiary Education Sector Report. Africa Region Human Development Working Paper Series No. 50. Washington DC: World Bank.

31. Wykstra, R. A. (1971). Human Capital Formation and Man Power Development. New York: The Free Press 